\title{
Potential of Biochar Application to Mitigate Salinity Stress in Eggplant
}

\section{Ved Parkash and Sukhbir Singh \\ Department of Plant and Soil Science, Texas Tech University, Lubbock, TX 79409}

Additional index words. salinity stress, biochar, photosynthesis, stomatal conductance, leaf temperature, shoot growth, root growth

\begin{abstract}
Salinity stress is among the major abiotic stresses prevailing in arid and semiarid areas such as the southern high plains of the United States. In these areas, both declining quality of groundwater and cultivation practices have resulted in increased accumulation of salts in the root zone. The occurrence of excessive salts in the root zone is detrimental for plant growth and economic yield. Recently, biochar has received a great consideration as a soil amendment to mitigate the detrimental impacts of salinity stress. However, the effectiveness of biochar to mitigate the salinity stress depends on the feedstock type, pyrolysis temperature and time, soil type and properties, and plant species. Therefore, a pot experiment in a greenhouse was conducted to 1) examine the effects of salinity stress on physiology, shoot and root growth, and yield of eggplant (Solanum melongena L.), and 2) evaluate the potential of hardwood biochar and softwood biochar to mitigate the damaging effects of salinity stress on eggplant. The experiment was conducted in a split-plot design with three salinity levels of irrigation water $\left[S_{0}\right.$ (control, $\left.0.04 \mathrm{dS} \cdot \mathrm{m}^{-1}\right), \mathrm{S}_{1}\left(2 \mathrm{dS} \cdot \mathrm{m}^{-1}\right)$, and $\left.\mathrm{S}_{2}\left(4 \mathrm{dS} \cdot \mathrm{m}^{-1}\right)\right]$ as main-plot factor and three biochar treatments $\left[B_{0}\right.$ (control, non-biochar), $B_{h}$ (hardwood biochar), and $B_{s}$ (softwood biochar)] as subplot factor with four replications. Results showed that stomatal conductance $\left(g_{S}\right)$ and photosynthesis rate decreased significantly, while leaf temperature and electrolyte leakage increased significantly with increase in irrigation water salinity levels. Root growth (root length density and root surface area density), shoot growth (plant height, stem diameter, and leaf area), and yield of eggplant declined with increase in levels of salinity stress. Biochar application helped to enhance $g_{S}$ and photosynthesis rate, and to decrease leaf temperature and electrolyte leakage in leaf tissues of plants. This resulted in better root growth, shoot growth, and fruit yield of eggplant in treatments amended with biochar than non-biochar (control) treatment. There was no significant difference in the effect of two types of biochars (hardwood and softwood biochar) on physiology, root growth, shoot growth, and yield of eggplant. Therefore, it can be concluded that softwood and hardwood biochars could be used to minimize the detrimental impacts of salinity stress in eggplant.
\end{abstract}

Salinity, drought, and heavy metal stresses are the major abiotic stresses affecting the crop production throughout the world (Ali et al., 2017; Osakabe et al., 2014; Parihar et al., 2015; Rizwan et al., 2016; Saifullah et al., 2018). However, salinity and drought stresses are the most abundant abiotic stresses that limit the crop production in the world. In a survey, it was found that on a global scale, around 1128 million hectares

Received for publication 28 Aug. 2020. Accepted for publication 24 Sept. 2020.

Published online 28 October 2020.

We thank Dr. Sanjit Deb and Dr. Rosalyn Shim for allowing us to use their laboratories and instruments to analyze some of the root and plant samples. We also thank Manpreet Singh, Azeezahmed Shaik, Bishwoyog Bhattarai, Kamalpreet Kaur Dhillon, Puneet Kaur Mangat, Atinderpal Singh, and Lakhvir Kaur Dhaliwal for their help in greenhouse and laboratory work.

This research received no external funding.

S.S. is the corresponding author. E-mail: s.singh@ ttu.edu.

This is an open access article distributed under the CC BY-NC-ND license (https://creativecommons. org/licenses/by-nc-nd/4.0/). such as soil aggregate stability, porosity, permeability, and infiltration (Kim et al., 2016). Salinity not only affects the soil properties, but it also influences the ecological balance of an area, and it reduces the crop productivity and economic returns. Under higher salinity conditions, the plant faces two key stresses, i.e., 1) osmotic stress and 2 ) ionic stress. Osmotic stress occurs in plants when there is an increased accumulation of salts in the soil solution in the root zone, resulting in inhibition of the water uptake by the roots. Because of reduced root water uptake, root and shoot growth declines. Along with this problem, a plant undergoes changes in several metabolic and physiological processes. These metabolic and physiological changes are similar to the ones caused by the water stress, such as decreased enzyme activity, protein synthesis, $\mathrm{CO}_{2}$ assimilation, $g_{\mathrm{S}}$, leaf water status and efficiency of photosystem II, and increased leaf temperature (Behboudian et al., 1986; García-Legaz et al., 1993; Munns, 2002). Ionic stress occurs due to the accumulation of ions in plants' tissues beyond the threshold limits at which the ions produce toxic effects. These threshold limits for ion toxicities are specific for each plant species, and sometimes they are specific for each genotype as well. Ionic stress results in premature leaf senescence, chlorosis, necrosis, and decreased cellular metabolic activities - including photosynthetic activity (Glenn et al., 1999; Panuccio et al., 2014; Yeo and Flowers, 1986; Zahir et al., 2012). Another detrimental effect of salinity on metabolic and physiological activities is the exacerbated synthesis of reactive oxygen species (ROS). The ROS are detrimental to DNA, protein synthesis, chlorophyll content, and membrane functioning. Reduction in these metabolic activities leads to inhibition of photosynthesis activity (Sahin et al., 2018). Additionally, under salinity stress, an increased accumulation of salts in the cells increases the cell wall permeability, which causes substantial increase in electrolyte leakage from the stricken cells (Ashraf and Harris, 2004; Lloyd et al., 1990). The major constituent of electrolyte leakage is $\mathrm{K}$, and $\mathrm{K}$ is a crucial element for the cation balance, protein synthesis, enzyme activity, osmoregulation, phloem transport, stomatal regulations, and photosynthetic activity (Wang et al., 2013). Thus higher electrolyte leakage from plant cells is harmful for plant processes and ultimately for plant growth.

Overall, salinity stress produces detrimental effects on plant physiology, growth, and yield. Therefore, to mitigate the effects of salinity stress, it is imperative to adopt practices that have the potential to remove excess soluble salts and/or exchangeable $\mathrm{Na}$ from the soil solution (Saifullah et al., 2018). Comprehensive research has been done over the years to find potential soil amendments to reclaim the salt-affected soils. Organic soil amendments such as compost, press mud, poultry manure, and farm-yard manure are extensively used to enhance the physical, chemical, and biological properties of the 
salt-affected soils in an effort to increase the soils' crop productivity (Lax et al., 1994; Oo et al., 2015; Srivastava et al., 2016; Walker and Bernal, 2008; Yaduvanshi and Swarup, 2005). However these organic amendments contain a high amount of decomposable organic substrates, necessitating their frequent reapplication. Repeated use of such organic amendments at high application rates is not economically feasible and also is not environment-friendly (increased emission of $\mathrm{CO}_{2}$ ) (Al-Wabel et al., 2019). However, biochar, which is an extremely stable organic material, has not been extensively studied to determine its potential to reclaim saltaffected soils.

Biochar is a carbon-rich material with a strong antidecomposability characteristic. Biochar is commonly produced by pyrolysis (thermal degradation) of biomass, especially agricultural residues under limited supply or the absence of oxygen in a closed furnace (Inyang et al., 2016; Lehmann and Joseph, 2009; Wang et al., 2017). The pyrolysis temperature can vary from $200{ }^{\circ} \mathrm{C}$ to $1000{ }^{\circ} \mathrm{C}$, and a slow pyrolysis is preferred for the biochar production (Lian and Xing, 2017). Biochar as a soil amendment has received much consideration in recent years. Biochar can increase crop productivity by improving the soil physical properties (aggregate stability, porosity, saturated hydraulic conductivity, water holding capacity, bulk density and particle density), chemical properties [nutrient retention, cation exchange capacity (CEC), EC, and $\mathrm{pH}]$, and biological properties (microbial population in the rhizosphere, microbial biomass $\mathrm{C}$ and $\mathrm{N}$, and enzymatic activities) (Lehmann and Joseph, 2009; Sohi et al., 2010). Another unique characteristic of biochar that makes it a suitable soil amendment for salt-affected soils is its high salt adsorption capacity (Thomas et al., 2013). Its high salt adsorption capacity is by virtue of its high surface area and CEC. Thus, biochar can be used to mitigate the negative impact of salt stress by minimizing the $\mathrm{Na}^{+}$uptake by plants (Akhtar et al., 2015a). For example, Akhtar et al. (2015a) found that a biochar application was quite effective to mitigate the salinity stress in potato, resulting in higher potato yield under salinity stress. In another study on wheat, Akhtar et al. (2015b) observed that the biochar transiently binds the $\mathrm{Na}^{+}$to reduce its uptake by the plant. Moreover, biochar application reduced osmotic stress by increasing soil water availability. Also, biochar application enhanced the supply of $\mathrm{K}^{+}, \mathrm{Ca}^{2+}$, and $\mathrm{Mg}^{2+}$ in the soil solution. It is also reported that biochar enhances the leaching of salts, thereby reducing the EC of the soil solution in the root zone (Chaganti et al., 2015; Lashari et al., 2015; Yue et al., 2016). Based on this review of the literature, it is interpreted that biochar has the potential to mitigate the salt stress by improving soil properties. But all types of biochar are not equally effective in mitigating the salt stress. Biochar effectiveness highly depends on the feedstock type, pyrolysis temperature and time, soil type and properties, and plant species (Saifullah et al., 2018). Consequently it is vital to evaluate the effectiveness of different types of biochar to mitigate the salinity stress in a wide range of crop species (especially in salt stress sensitive, high-value vegetable crops) for making general recommendations for biochar as a soil amendment to mitigate the salinity stress in crops.

Eggplant is a high-value vegetable crop. Its nutritional value is comparable to tomato, both being a rich source of vitamins and minerals (Abbas et al., 2010). Eggplant has a low production cost and a high antioxidant value (Hegazi et al., 2015). Eggplants are cultivated around the world; the area under their cultivation is around 1.86 million hectares (FAO, 2018). Eggplant is moderately sensitive to salt stress (Abbas et al., 2010; Ünlükara et al., 2010). The recommended threshold EC for eggplant cultivation ranges from $1.1-1.5 \mathrm{dS} \cdot \mathrm{m}^{-1}$ (Heuer et al., 1986; Ünlükara et al., 2010). Being an important crop, it is essential to understand its response and adaptation to increased levels of salinity stress, to develop efficient crop cultivation practices and breeding strategies.

From the literature review, it became evident that a very limited number of studies have evaluated the effect of salinity stress on physiology and root growth parameters of eggplant. Additionally, to the best of our knowledge, there is no study on the effect of biochar to mitigate salt stress in the eggplant. Therefore, the objectives of this study were to 1) examine the effects of salinity stress on physiology, shoot and root growth, and yield of eggplant, and 2) evaluate the potential of hardwood biochar and softwood biochar to mitigate the damaging effects of salinity stress on eggplant.

\section{Materials and Methods}

Growing conditions and planting material. A two-season study was conducted from 26 June 2019 to 8 Oct. 2019 (Expt. 1) and from 19 Oct. 2019 to 3 Mar. 2020 (Expt. 2) in a greenhouse located at Horticulture Gardens and Greenhouse Complex of Texas Tech University, Lub-

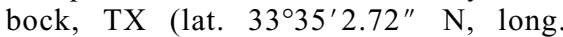
$\left.101^{\circ} 53^{\prime} 12.95^{\prime \prime} \mathrm{W}\right)$. The average air temperature inside the greenhouse was maintained at $30{ }^{\circ} \mathrm{C}$ during the day and $25^{\circ} \mathrm{C}$ during the night for both experiment periods. The greenhouse was sun-lit, and most of the sunlight was transmitted inside the greenhouse.

A sandy-clay-loam soil, which is a common soil type around the study site, was used in our study. The soil was collected from the upper 0- to 20-cm layer of a field located at New Deal Research farm, Texas Tech

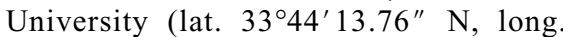
$\left.101^{\circ} 43^{\prime} 58.04^{\prime \prime} \mathrm{W}\right)$. The soil was air-dried, sieved using 2-mm sieve, and thoroughly hand-mixed before use. Two biochars that differ in feedstock type, i.e., 1) hardwood biochar made from oak and 2) softwood biochar made from pine, were procured from Wakefield Biochar, Columbia, MO. Chemical properties of the two types of biochar are reported in Table 1. This study included three biochar treatments: 1) control (non-biochar, $\left.\mathrm{B}_{0}\right)$; 2) hardwood biochar $\left(\mathrm{B}_{\mathrm{h}}\right)$; and 3) softwood biochar $\left(\mathrm{B}_{\mathrm{s}}\right)$. Each biochar was applied at $5 \%$ by weight and thoroughly mixed into the soil. An application rate of biochar at $5 \%$ by weight was used based on the review of

Table 1. Chemical properties of hardwood and softwood biochar.

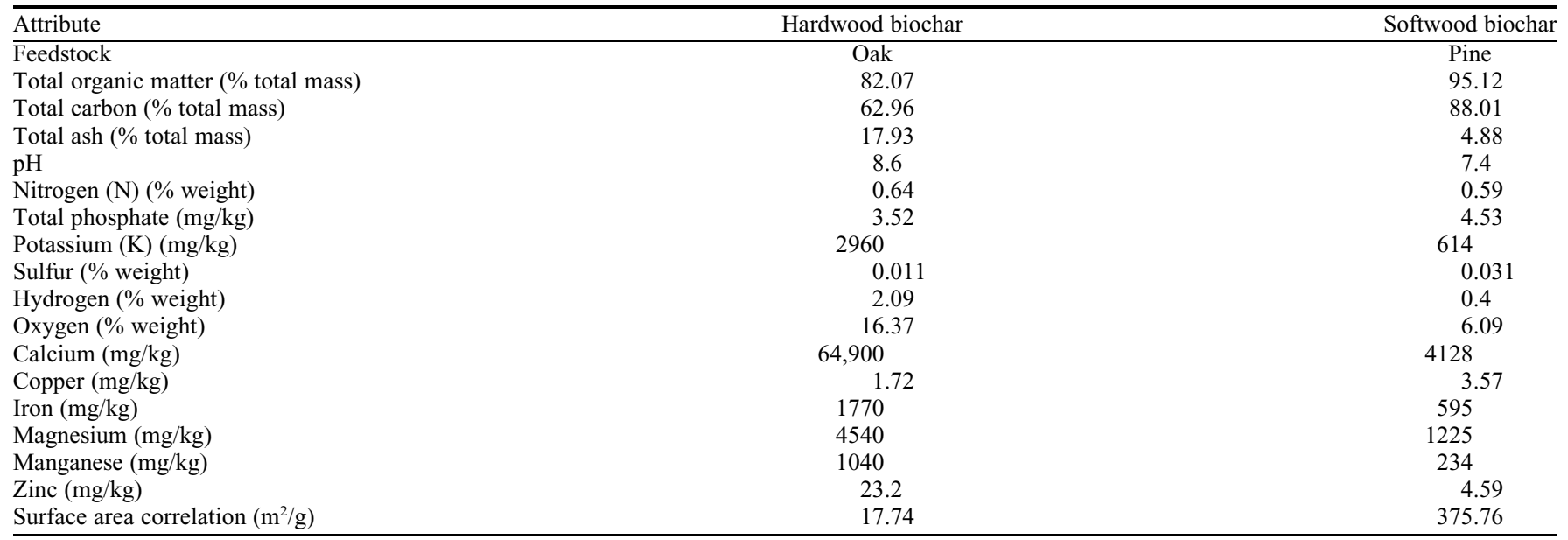


the literature, which suggests that a 5\% application rate was most commonly used; and suggests that at this application rate, biochar was effective in mitigating the salinity stress (Akhtar et al., 2015a, 2015b, 2015c; Farhangi-Abriz and Torabian, 2018a; Hammer et al., 2015; Kim et al., 2016; NikpourRashidabad et al., 2019). A total of $12.5 \mathrm{~kg}$ of soil-biochar mixture was placed into plastic pots of 12-L capacity. For control treatment, only soil was filled in the pots. A woven groundcover cloth was placed inside, at the bottom of the pot, to prevent the soil from draining out through drainage holes. River pebbles that had a diameter of about $2 \mathrm{~cm}$ were placed in a single layer over the cloth and underneath the soil to allow the free drainage of excess water. While filling, the pot was tapped after every 5 -cm depth increment of soil filled in the pot, to achieve the homogenous soil profile. After filling, pots were saturated with water to stabilize the soil in the pots.

Seeds of Jaylo variety of eggplant were purchased from Johnny's Selected Seeds, Winslow, ME. Eggplant seeds were sown in multicell trays filled with soilless potting mix. Homogenous and disease-free seedlings were transplanted into main pots at 25 and $38 \mathrm{~d}$ after sowing during Expt. 1 and Expt. 2, respectively. The recommended dose of Fertmax Grow A and B fertilizer (CleanGrow Inc., Sacramento, CA) was applied equally to
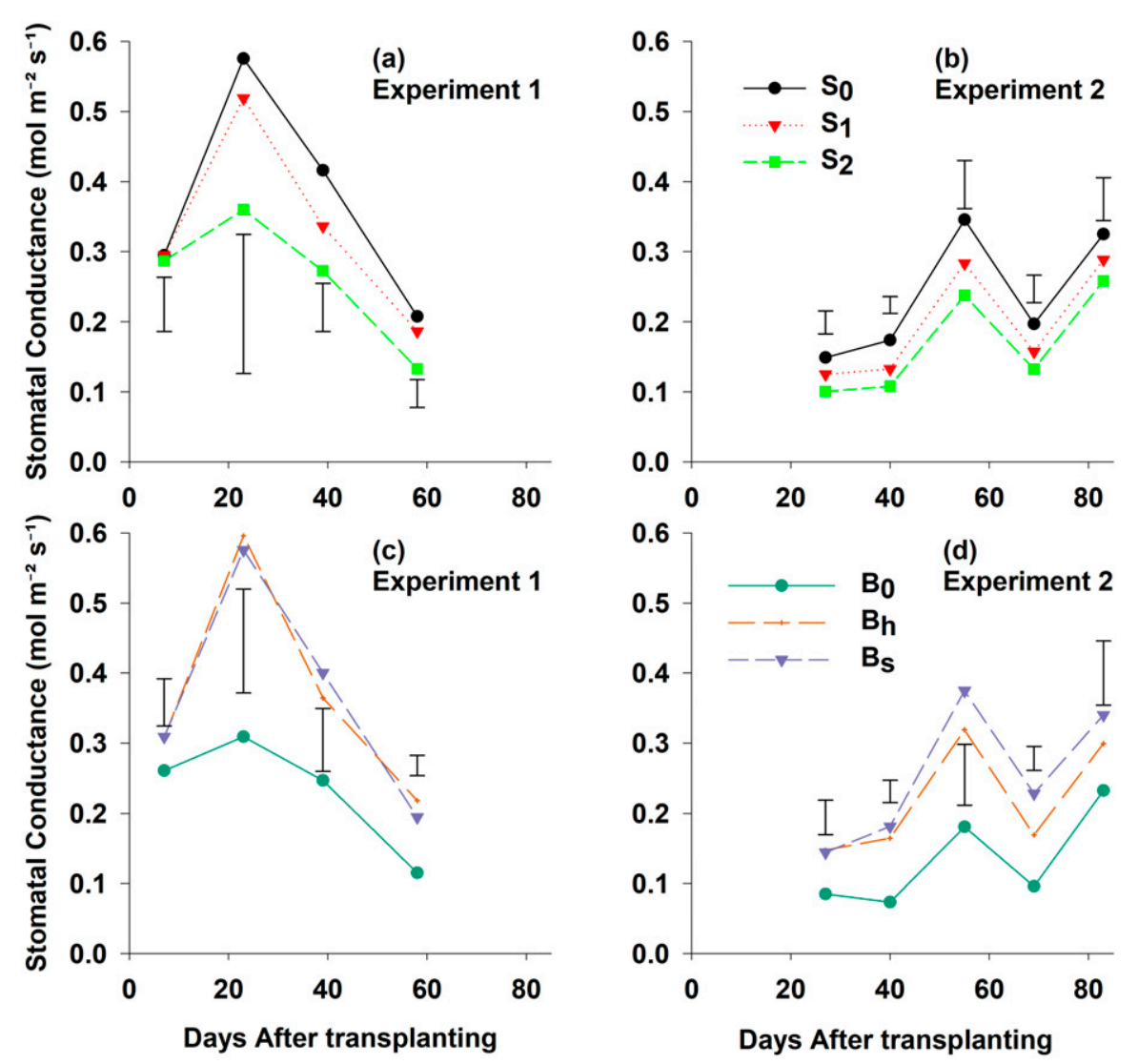

Fig. 1. Effect of salinity treatments ( $\mathbf{A}$ and $\mathbf{B})$ and biochar treatments $(\mathbf{C}$ and $\mathbf{D})$ on stomatal conductance of eggplant measured at different days after transplanting in Expt. 1 (A and $\mathbf{C}$ ) and Expt. 2 (B and D). Bars indicate least significant difference at $P \leq 0.05$.

each pot. During Expt. 1, the crop was infested with red spider mites (Tetranychus urticae), and infestation was severe during the fruiting stage. A recommended dose of Agropest insecticide (Agro Research International LLC) was used to control the red spider mites. Due to severe red spider mite infestation, crop growth and fruit yield was severely affected during Expt. 1.

Salinity treatments. Salinity treatments consisted of three salinity levels of irrigation water, i.e., 1) tap water (control, $0.04 \mathrm{dS} \cdot \mathrm{m}^{-1}$, $\left.\mathrm{S}_{0}\right)$; 2$) 2 \mathrm{dS} \cdot \mathrm{m}^{-1}\left(\mathrm{~S}_{1}\right)$; and 3) $4 \mathrm{dS} \cdot \mathrm{m}^{-1}\left(\mathrm{~S}_{2}\right)$. An estimated amount of $\mathrm{NaCl}$ was dissolved in tap water to prepare the required salinity levels of irrigation water, and the final EC of the solution was checked with an EC meter (an Orion Star A325 pH/Conductivity Portable Multiparameter Meter). Manual application of salinity treatments was started at $7 \mathrm{~d}$ after transplanting in each experiment. After that, saline irrigation water treatments were continuously applied at a 2-4 d interval.

Physiological parameters. Photosynthetic rate $\left(\mathrm{P}_{\mathrm{n}}\right), g_{\mathrm{S}}$, and leaf-air temperature difference (LATD) were measured from the youngest, fully expanded, illuminated and disease-free leaf between 11:00 and 14:00 h using Portable Photosynthesis System (Model LI-COR 6800; Lincoln, NE). Measurements were taken from a $6-\mathrm{cm}^{2}$ leaf area by maintaining $400 \mu \mathrm{mol} \cdot \mathrm{mol}^{-1}$ of $\mathrm{CO}_{2}, 500$ $\mu \mathrm{mol} \cdot \mathrm{m}^{-2} \cdot \mathrm{s}^{-1}$ of photosynthetic active radia- tion (PAR), and $65 \%$ relative humidity inside the measuring chamber. Physiological measurements were taken four times in Expt. 1 and five times in Expt. 2 at different days after transplanting.

Electrolyte leakage was measured twice at a 1-week interval during the fruiting stage in both the experiments. For measurement of electrolyte leakage, leaf discs were excised from two of the youngest, fully expanded, and disease-free leaves of a plant. A total of 10 leaf discs (5 discs from each of the two leaves) per plant were excised using a singlehole paper punch (a Staples 1-hole punch) and were put into a $50-\mathrm{ml}$ falcon tube containing $30 \mathrm{ml}$ of Milli-q water. Falcon tubes containing the leaf discs were brought to the laboratory and were kept on a platform shaker $(125 \mathrm{rpm})$ for about $30 \mathrm{~min}$ to completely wet leaf discs to allow electrolytes to diffuse into the water solution. Leaf discs samples were then left at room temperature for 5-6 $\mathrm{h}$ to allow the electrolytes to diffuse into the water, and then initial $\mathrm{EC}\left(\mathrm{EC}_{1}\right)$ of the solution was measured with an $\mathrm{EC}$ meter. After taking the $\mathrm{EC}_{1}$, samples were boiled for $1 \mathrm{~h}$ by keeping them in a water bath, and then samples were allowed to cool to room temperature for final $\mathrm{EC}\left(\mathrm{EC}_{2}\right)$ measurements. The electrolyte leakage was estimated using the following formula: electrolyte leakage percent $(\mathrm{EL} \%)=\mathrm{EC}_{1} / \mathrm{EC}_{2} \times 100($ Sahin et al., 2018).

Shoot growth and yield parameters. Plant height from the soil surface to the tip of a plant was measured at the end of the experiments. Stem diameter was also measured at the end of the experiments. Eggplant fruits were picked at 3-4 d intervals when they had achieved the harvestable size. The number of fruits per plant and fresh fruit weight were recorded for each plant at each harvest. At the end of each experiment, each plant was harvested, and leaves were separated from stem and branches to measure the leaf area using a bench-top leaf area meter (an LI3100C Area Meter). Leaf and stem samples were oven-dried to a constant weight at $70^{\circ} \mathrm{C}$, and dry shoot weight for each plant was recorded.

Root growth parameters. To collect root samples, soil core samples were taken using a split-core sampler (with a 5-cm diameter and a $30-\mathrm{cm}$ length) from one complete depth (22 $\mathrm{cm}$ ) of the pot at the end of each experiment. Samples were collected $3 \mathrm{~cm}$ away from the base of the stem. Soil core samples were placed in Ziploc bags and stored at $4{ }^{\circ} \mathrm{C}$ until the roots were washed out (Kage et al., 2000; Singh, 2019). Each sample was washed separately by placing the soil core sample on the fine-mesh sieve strainer. Another strainer was placed vertically below the strainer containing the soil core sample to collect the roots escaping from the upper strainer. Water with little pressure was used to drain the soil from the meshes. After draining the soil from both the meshes, roots were manually taken out using a forceps and stored in a $15 \%$ ethanol $\left(\mathrm{cm}^{3} \cdot \mathrm{cm}^{-3}\right)$ solution in $50-\mathrm{ml}$ falcon tubes at $4{ }^{\circ} \mathrm{C}$ for later root analysis (Singh, 2019). Washed root samples were scanned using a flatbed scanner (STD 4800, 
EPSON V800 Photo Dual Lens System; Reagent Instruments Inc.) at a 600-dpi resolution. Scanned images were analyzed for root length density (RLD) [root length per unit volume of soil, $\left.\left(\mathrm{cm} \cdot \mathrm{cm}^{-3}\right)\right]$, root surface area density (RSAD) [root surface area per unit volume of soil $\left(\mathrm{cm}^{2} \cdot \mathrm{cm}^{-3}\right)$, and root fineness classification (percentage of total root length in a given diameter class) using WinRHIZO Pro version 2016a software (Regent Instruments Inc., Quebec, Canada). Total root length was divided into three diameter classes, i.e., 1) $0-0.5 \mathrm{~mm}, 2$ ) 0.5 $1.0 \mathrm{~mm}$, and 3) $>1 \mathrm{~mm}$, to get the percent of total root length lying in given a diameter class.

Statistical analysis. The experiment was laid-out in a blocked split plot design and all experimental units were replicated four times. Irrigation salinity levels (control, $2 \mathrm{dS} \cdot \mathrm{m}^{-1}$ and 4 $\mathrm{dS} \cdot \mathrm{m}^{-1}$ ) were the main-plot factor; and biochar treatments [non-biochar (control, $\mathrm{B}_{0}$ ), hardwood biochar $\left(\mathrm{B}_{\mathrm{h}}\right)$, and softwood biochar $\left(\mathrm{B}_{\mathrm{s}}\right)$ ] were the subplot factor. Data for each parameter were analyzed using ANOVA in $\mathrm{R}$ version 3.5.2, using Agricolae package version 1.2-8. The least significant difference test at $5 \%$ significance level was used to separate means. Figures were created using SigmaPlot version 14 (Systat Software, San Jose, CA).

\section{Results and Discussion}

Plant physiology. The $g_{\mathrm{S}}$ of eggplant declined with increased levels of salinity (Fig. 1). The $g_{\mathrm{S}}$ of the $\mathrm{S}_{0}$ treatment did not
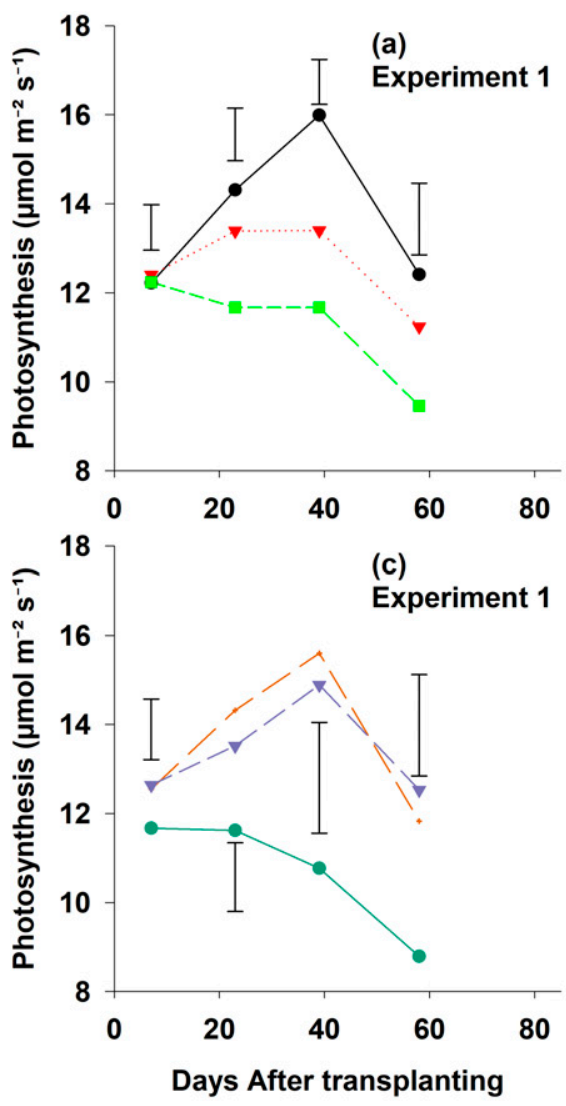

differ significantly from the $S_{1}$ treatment on most of the measurement days in both experiments. However, $g_{\mathrm{S}}$ of the $\mathrm{S}_{0}$ treatment was significantly higher than the $\mathrm{S}_{2}$ treatment on all measurement days. Biochar addition had a significant positive effect on $g_{\mathrm{S}}$ compared with the control (non-biochar) (Fig. 1). The $g_{\mathrm{S}}$ of $\mathrm{B}_{\mathrm{h}}$ and $\mathrm{B}_{\mathrm{s}}$ treatments was significantly higher than the $g_{\mathrm{S}}$ of $\mathrm{B}_{0}$ on most of the measurement days in both experiments. There was no significant difference in $g_{S}$ between $\mathrm{B}_{\mathrm{h}}$ and $\mathrm{B}_{\mathrm{s}}$.

A decline in $g_{\mathrm{S}}$ in higher salinity levels can be attributed to reduction in root water uptake. In higher salinity treatments, increased accumulation of salts in the root zone decreased the osmotic potential of soil, which inhibited root water uptake. A decline in $g_{\mathrm{S}}$ with increased levels of salinity is also observed in other studies (Akhtar et al., 2015a; Baath et al., 2017; Colla et al., 2006; Delfine et al., 1999; Singh et al., 2014). Biochar addition improves soil properties that ultimately enhances water holding capacity of the soil. So, higher $g_{\mathrm{S}}$ in treatments amended with biochar, compared with non-biochar (control), can be attributed to an increase in plant water availability under biochar application. Higher plant water availability with biochar application under salinity stress is reported in several studies (Akhtar et al., 2015a; Lehmann and Joseph, 2009; Sohi et al., 2010).

Increased levels of salinity had a suppressing effect on $\mathrm{P}_{\mathrm{n}}$. The $\mathrm{P}_{\mathrm{n}}$ of the $\mathrm{S}_{0}$
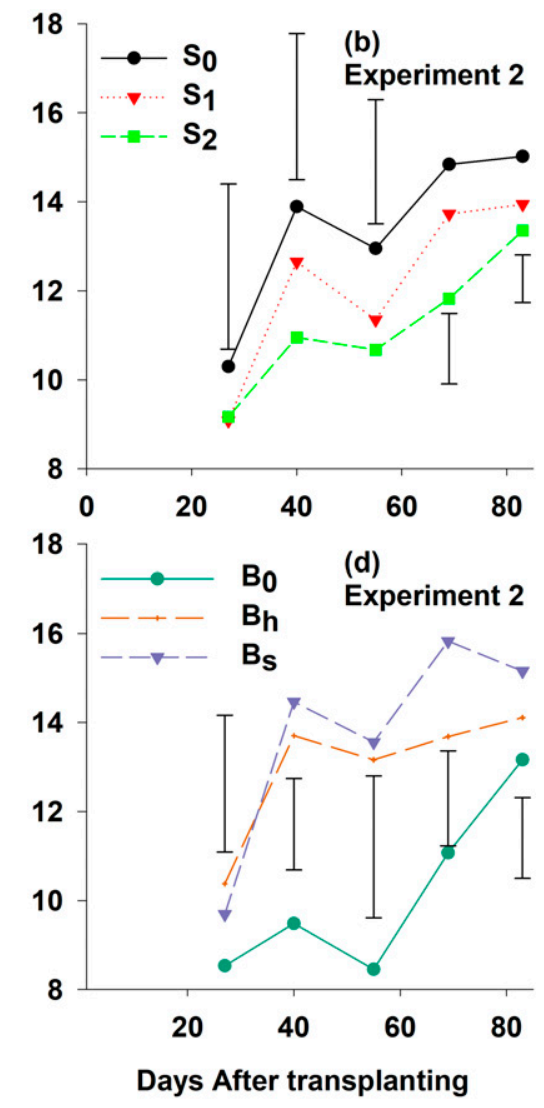

Fig. 2. Effect of salinity treatments (A and $\mathbf{B})$ and biochar treatments $(\mathbf{C}$ and $\mathbf{D})$ on photosynthesis rate of eggplant measured at different days after transplanting in Expt. 1 (A and C) and Expt. 2 (B and D). Bars indicate least significant difference at $P \leq 0.05$. treatment was significantly higher than the $\mathrm{S}_{1}$ and $\mathrm{S}_{2}$ treatments on most of the measurement days in both experiments (Fig. 2). The $\mathrm{P}_{\mathrm{n}}$ of treatments amended with biochar was significantly higher than control (nonbiochar) treatment on all the measurement days. The $\mathrm{P}_{\mathrm{n}}$ of $\mathrm{B}_{\mathrm{h}}$ and $\mathrm{B}_{\mathrm{s}}$ was comparable with each other (Fig. 2).

Photosynthesis is among the important complex physiological processes impacted by the salinity stress (Sahin et al., 2018). Generally, $\mathrm{P}_{\mathrm{n}}$ decreases in response to decreased $g_{\mathrm{S}}$ (Baath et al., 2017; Parkash and Singh, 2020; Singh et al., 2016; Stępień and Kłbus, 2006). In the current study, we also found a decrease in $\mathrm{P}_{\mathrm{n}}$ with the corresponding decrease in $g_{\mathrm{S}}$. In both experiments, differences in $\mathrm{P}_{\mathrm{n}}$ among salinity treatments became significant as crop approached maturity. This can be due to an increased concentration of accumulated salts in the root zone over time, which might have increased the osmotic stress. Increased osmotic stress resulted in a decreased $g_{\mathrm{S}}$, which ultimately led to the reduced $\mathrm{CO}_{2}$ supply to leaves for photosynthesis in the higher salinity treatments. Results of this study, that $P_{n}$ declined with increased salinity level, were consistent with the results of other studies on salinity stress (Akhtar et al., 2015a; Baath et al., 2017; Colla et al., 2006; Delfine et al., 1999; Singh et al., 2014). Higher $P_{n}$ in treatments amended with biochar can be attributed to higher water availability for transpiration (higher $g_{\mathrm{S}}$ and an increased supply of $\mathrm{CO}_{2}$ to the leaves) in these treatments, compared with the control (non-biochar). Increased $\mathrm{P}_{\mathrm{n}}$ in biochar amended treatments under salinity stress was also observed in other studies (Akhtar et al., 2015a, 2015b).

Leaf temperature increased with increased levels of salinity, resulting in less negative LATD in higher salinity treatments (Fig. 3). Less negative LATD means more warm leaves. The LATD was significantly less negative in the $S_{1}$ and $S_{2}$ treatments, compared with $\mathrm{S}_{0}$ on most of the measurement days, in both experiments. Biochar addition helped to maintain a lower leaf temperature, resulting in significantly more negative LATD in treatments amended with biochar than the control (non-biochar) (Fig. 3). The LATD was not significantly different between the $\mathrm{B}_{h}$ and $\mathrm{B}_{\mathrm{s}}$ treatments.

Reduced transpiration rate might have increased the leaf temperature in the higher salinity treatments. With an increase in salinity levels, osmotic stress in the root zone increases, which results in a reduction in transpiration rate (Testi et al., 2008). Because of reduced transpiration, latent heat of vaporization is not withdrawn from the leaf, resulting in a higher leaf temperature and less negative LATD in stressed plants. In this study, LATD became less negative with increased levels of salinity, which suggests that the leaf temperature was comparatively higher in stressed plants. Higher leaf temperature inhibits the activity of photosystem II, inactivates Rubisco, and disintegrates plasmalemma (Camejo et al., 2005). All these 

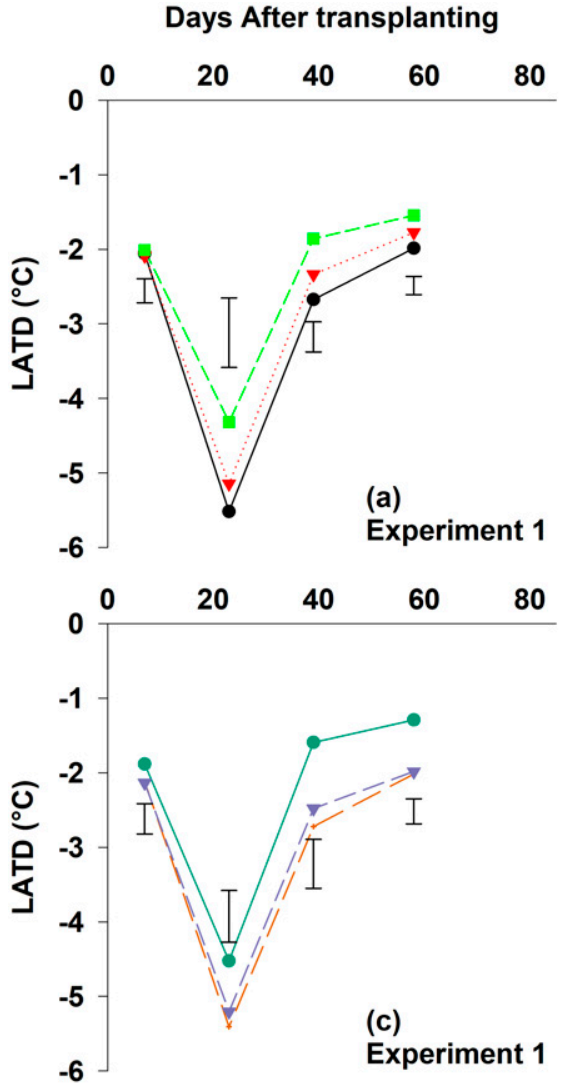

Fig. 3. Effect of salinity treatments (A and $\mathbf{B})$ and biochar treatments $(\mathbf{C}$ and $\mathbf{D})$ on leaf-air temperature difference (LATD) of eggplant measured at different days after transplanting in Expt. 1 (A and $\mathbf{C}$ ) and Expt. 2 (B and D). Bars indicate least significant difference at $P \leq 0.05$.

metabolic activities have a direct effect on photosynthesis activity, which subsequently affect crop yield. More negative LATD values were found in the treatments amended with biochar than the control (non-biochar), which can be attributed to an increase in plant water availability for transpiration in treatments amended with biochar compared with the control.

In this study, electrolyte leakage was higher in higher salinity levels. Electrolyte leakage did not differ significantly between $\mathrm{S}_{0}$ and $\mathrm{S}_{1}$, while it was significantly higher in $\mathrm{S}_{2}$ than $\mathrm{S}_{0}$ in Expt. 1 (Fig. 4). In Expt. 2, electrolyte leakage was significantly higher in $\mathrm{S}_{1}$ and $\mathrm{S}_{2}$ compared with $\mathrm{S}_{0}$. Treatments amended with biochar had significantly lower electrolyte leakage than the control (non-biochar) (Fig. 4). In Expt. 1, electrolyte leakage was not significantly different between $B_{s}$ and $B_{h}$, but it was significantly higher in $B_{h}$ than $B_{s}$ in Expt. 2.

Electrolyte leakage occurs in response to stress-induced injuries to plant tissues (Bajji et al., 2002; Blum and Ebercon, 1981; Levitt and Levitt, 1987). Electrolyte leakage is an indirect method to measure the integrity and stability of the cell membrane. The cell membrane acts as a barrier, and its disintegration results in the death of the cell (Mcneil and Steinhardt, 1997). Under salinity stress, an increase in the accumulation of salts in the plant cells occurs, which results in an increase in cell wall permeability. Because of increased cell wall permeability, a substantial increase in electrolyte leakage occurs from the stricken cells (Ashraf and Harris, 2004; Lloyd et al., 1990). Cell wall permeability increases, probably due to increased generation of ROS under stress conditions. The ROS cause oxidative damage to lipids, which are the main component of the cell membrane (Dionisio-Sese and Tobita, 1998). The major part of electrolytes leaking from the cells consists of $\mathrm{K}$; and $\mathrm{K}$ is the primary element for cation-anion balance, energy transfer, osmoregulation, phloem transport, protein synthesis, enzyme activity, stomatal adjustments, and photosynthesis activity (Wang et al., 2013). Thus increased electrolyte leakage is detrimental for plant metabolic activities and physiological processes, and it exerts a negative impact on the plant growth and yield. Biochar has high adsorption capacity, which helps to mitigate the detrimental impact of salinity by minimizing the uptake of $\mathrm{Na}^{+}$(Akhtar et al., 2015a). Due to this function of biochar, there was less accumulation of salts in plant tissues, resulting in lower electrolyte leakage in treatments amended with biochar in comparison with the control (non-biochar), even under higher salinity levels. Lashari et al. (2015) found that electrolyte leakage was reduced in maize with biochar application in salt-affected soil.

Shoot growth and fruit yield. The salinity and biochar treatments had a considerable effect on plant growth and yield parameters.
Effects of salinity and biochar treatments on plant height of eggplant are shown in Table 2. In Expt. 1, plant height did not differ significantly between $S_{0}$ and $S_{1}$, while it was significantly higher in $S_{0}$ and $S_{1}$ than in $S_{2}$. In Expt. 2, plant height was comparable between $S_{0}$ and $S_{1}$ and also between $S_{1}$ and $\mathrm{S}_{2}$. It was significantly higher in $\mathrm{S}_{0}$ than in $\mathrm{S}_{2}$. The plant height was significantly higher in the treatments amended with biochar than the control (non-biochar) in both experiments (Table 2). The plant height was not significantly different between $B_{h}$ and $B_{s}$ in both experiments. In similar studies by Usman et al. (2016) on tomato and Akhtar et al. (2015b) on wheat, it was found that salinity stress decreased the plant height while biochar addition enhanced the plant height.

Increased levels of salinity suppressed the stem diameter growth (Table 2). In Expt. 1, the stem diameter of the $S_{0}$ treatment was not significantly different from $S_{1}$, while the stem diameter of the $\mathrm{S}_{0}$ treatment was significantly higher than $S_{2}$. In Expt. 2, the stem diameter was significantly higher in the $S_{0}$ treatment than in the $S_{1}$ and $S_{2}$ treatments. The treatments amended with biochar had significantly greater stem diameters than the control (non-biochar) treatment, and $\mathrm{B}_{\mathrm{h}}$ and $\mathrm{B}_{\mathrm{s}}$ had a comparable effect on the stem diameter growth (Table 2). Agbna et al. (2017) also observed that the stem diameter was greater in treatments amended with biochar than the non-biochar (control) treatment under salt stress.

The leaf area of eggplant decreased with increased levels of salinity. Leaf area was significantly higher in $S_{0}$ compared with $S_{2}$, while it did not differ significantly between $\mathrm{S}_{1}$ and $\mathrm{S}_{2}$ in both experiments. Biochar had a positive effect on the leaf area. However, the leaf area did not differ significantly between $\mathrm{B}_{h}$ and $\mathrm{B}_{\mathrm{s}}$ in both experiments. Akhtar et al. $(2015 \mathrm{c})$ found that the leaf area of maize decreased with increased salinity levels, while biochar addition enhanced the leaf area under salt stress.

Plants grown at higher salinity levels accumulated less dry shoot biomass (Table 2). In both experiments, dry shoot weight was significantly higher in $\mathrm{S}_{0}$ than $\mathrm{S}_{2}$, while it was comparable between $S_{0}$ and $S_{1}$ and also between $S_{1}$ and $S_{2}$. In the treatments amended with biochar, dry shoot weight was significantly higher compared with the control (nonbiochar), while dry shoot weight was not significantly different between $\mathrm{B}_{h}$ and $\mathrm{B}_{\mathrm{s}}$. A decrease in dry shoot biomass and a positive effect of biochar application on shoot biomass under salt stress are supported by the results of other studies (Agbna et al., 2017; Akhtar et al., 2015b, 2015c; Usman et al., 2016).

The number of fruits produced per plant was less in higher salinity levels (Table 2). In Expt. 1, the number of fruits per plant did not differ significantly between $\mathrm{S}_{0}$ and $\mathrm{S}_{1}$ and also between $S_{1}$ and $S_{2}$, but it was significantly different between $S_{0}$ and $S_{2}$. In Expt. 2, the number of fruits per plant was significantly different among the salinity treatments. The $\mathrm{S}_{0}$ had the highest number of fruits per plant, and 
$\mathrm{S}_{2}$ had the least number of fruits per plant. In Expt. 1, the number of fruits per plant did not differ significantly among the biochar treatments. In Expt. 2, the treatments amended with biochar produced significantly more number of fruits per plant than the control

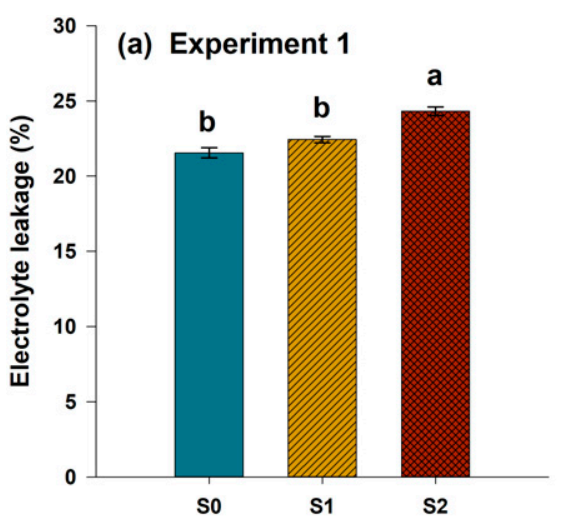

Salinity treatments

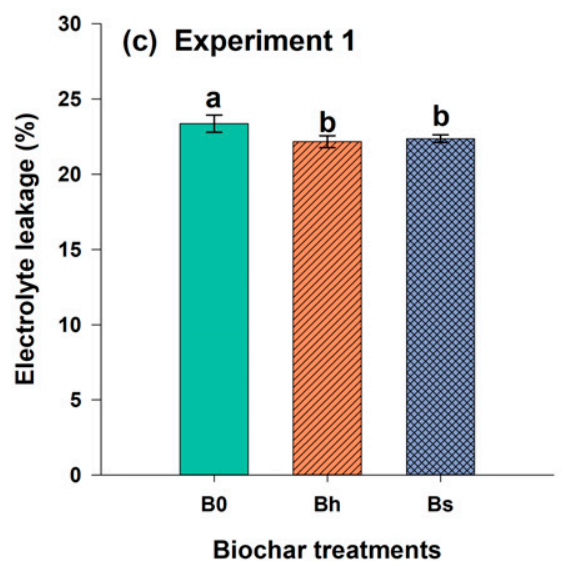

(non-biochar), but it was comparable between $B_{h}$ and $B_{s}$. Average fruit weight did not differ significantly among the salinity treatments and biochar treatments in both of the experiments. Fresh fruit yield was significantly different among the salinity treatments. In Expt. 1, fresh fruit yield decreased by $27 \%$ in $\mathrm{S}_{1}$ and by $51 \%$ in $\mathrm{S}_{2}$ compared with $\mathrm{S}_{0}$; while in Expt. 2 , yield decreased by $15 \%$ in $S_{1}$ and by $34 \%$ in $S_{2}$ compared with $\mathrm{S}_{0}$. Biochar addition had a significant beneficial effect on fruit yield. Both types of biochar had a comparable effect on the fruit yield. In Expt. 1, fresh fruit yield was higher by $29 \%$ and $61 \%$ in $\mathrm{B}_{\mathrm{h}}$ and $\mathrm{B}_{\mathrm{s}}$, respectively; while in Expt. 2, it was higher by $141 \%$ and $146 \%$ in $B_{h}$ and $B_{s}$, respectively, compared with the control. Based on these results, it can be interpreted that relative differences in total fruit yield per plant among the treatments were more affected by differences in number of fruits per plant than average fruit weight. A negative effect of increased salinity level and a positive effect of biochar application on fruit yield and yield parameters (the number of fruits per plant and average fruit weight) are also reported in other studies (Agbna et al., 2017; Akhtar et al., 2015a; Usman et al., 2016).

A decrease in plant growth with increased levels of salinity of irrigation water can be ascribed to increased osmotic stress and reduced water uptake by plants in higher salinity treatments, which is evident from reduced $g_{\mathrm{S}}$ in higher salinity treatments. A decrease in $g_{\mathrm{S}}$ reduces $\mathrm{CO}_{2}$ assimilation (Baath et al., 2017; Stępień and Kłbus, 2006). Other than stomatal closure effect, $\mathrm{CO}_{2}$ assimilation is also affected by increased leaf temperature. Increased leaf temperature negatively influences the activity of photosystem II. Photosystem II provides reducing power and energy for $\mathrm{CO}_{2}$ assimilation (Camejo et al., 2005). Results of LATD suggest that leaf temperature was relatively more in the higher salinity treatments, which had reduced $\mathrm{CO}_{2}$ assimilation in the stressed treatments. Additionally, increased electrolyte leakage under salinity stress results in oxidative damage, which disturbs the membrane system and negatively affects the photosynthesis and respiration (Sahin et al., 2018). The results

Fig. 4. Effect of salinity treatments $(\mathbf{A}$ and $\mathbf{C})$ and biochar treatments ( $\mathbf{B}$ and $\mathbf{D})$ on electrolyte leakage of eggplant in Expt. 1 (A and B) and Expt. 2 (C and D). Error bars indicate standard errors of mean $(n=4)$. Bars with the same letter are not significantly different at $P \leq 0.05$

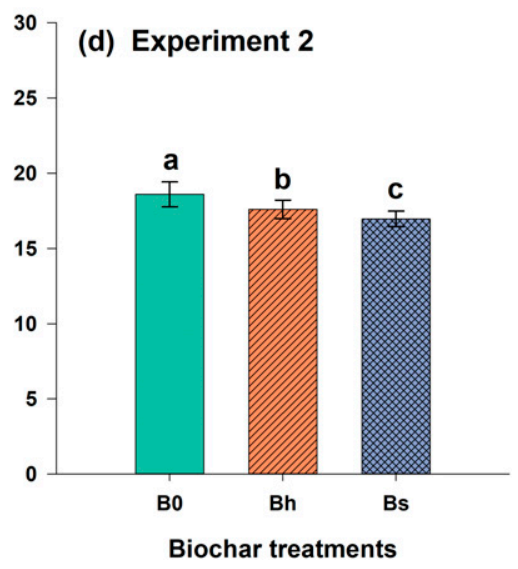

Table 2. Effect of salinity (S) and biochar (B) on growth, yield parameters, and yield of eggplant in experiments 1 and 2 at Lubbock, TX.

\begin{tabular}{|c|c|c|c|c|c|c|c|}
\hline Treatments & $\begin{array}{c}\text { Plant } \\
\text { ht }(\mathrm{cm})\end{array}$ & $\begin{array}{l}\text { Stem diam } \\
(\mathrm{mm})\end{array}$ & $\begin{array}{c}\text { Leaf area } \\
\left(\mathrm{cm}^{2} / \text { plant }\right)\end{array}$ & $\begin{array}{c}\text { Dry shoot wt } \\
(\mathrm{g} / \text { plant })\end{array}$ & $\begin{array}{l}\text { Number of } \\
\text { fruits }\end{array}$ & $\begin{array}{l}\text { Avg fruit } \\
\text { wt }(\mathrm{g})\end{array}$ & $\begin{array}{l}\text { Fresh fruit yield } \\
\quad(\mathrm{g} / \text { plant })\end{array}$ \\
\hline \multicolumn{8}{|l|}{ Expt. 1} \\
\hline \multicolumn{8}{|l|}{ Salinity level (S) } \\
\hline $\mathrm{S}_{0}$ (control) & $82.9 \mathrm{a}^{\mathrm{z}}$ & $9.8 \mathrm{a}$ & $4369 \mathrm{a}$ & $55.2 \mathrm{a}$ & $2.3 \mathrm{a}$ & $99.3 \mathrm{a}$ & $218 \mathrm{a}$ \\
\hline $\mathrm{S}_{1}\left(2 \mathrm{dS} \cdot \mathrm{m}^{-1}\right)$ & $78.4 \mathrm{a}$ & $9.2 \mathrm{ab}$ & $3193 \mathrm{ab}$ & $39.9 \mathrm{ab}$ & $1.8 \mathrm{ab}$ & $92.7 \mathrm{a}$ & $160 \mathrm{~b}$ \\
\hline $\mathrm{S}_{2}\left(4 \mathrm{dS} \cdot \mathrm{m}^{-1}\right)$ & $64.1 \mathrm{~b}$ & $7.9 \mathrm{~b}$ & $1978 \mathrm{~b}$ & $25.0 \mathrm{~b}$ & $1.4 \mathrm{~b}$ & $74.4 \mathrm{a}$ & $107 \mathrm{c}$ \\
\hline \multicolumn{8}{|l|}{ Biochar (B) } \\
\hline $\mathrm{B}_{0}$ (non-biochar) & $61.4 \mathrm{~b}$ & $7.5 \mathrm{~b}$ & $1654 \mathrm{~b}$ & $20.7 \mathrm{~b}$ & $1.6 \mathrm{a}$ & $84.4 \mathrm{a}$ & $128 \mathrm{~b}$ \\
\hline $\mathrm{B}_{\mathrm{h}}$ (hardwood) & $79.8 \mathrm{a}$ & $9.2 \mathrm{a}$ & $3485 \mathrm{a}$ & $44.2 \mathrm{a}$ & $1.8 \mathrm{a}$ & $91.5 \mathrm{a}$ & $165 \mathrm{ab}$ \\
\hline $\mathrm{B}_{\mathrm{s}}$ (softwood) & $81.9 \mathrm{a}$ & $10.1 \mathrm{a}$ & $4285 \mathrm{a}$ & $54.9 \mathrm{a}$ & $2.2 \mathrm{a}$ & $92.8 \mathrm{a}$ & $206 \mathrm{a}$ \\
\hline$(\mathrm{SXB})^{\mathrm{z}}$ & NS & NS & NS & NS & NS & NS & NS \\
\hline \multicolumn{8}{|l|}{ Expt. 2} \\
\hline \multicolumn{8}{|l|}{ Salinity level (S) } \\
\hline $\mathrm{S}_{0}$ (control) & $90.3 \mathrm{a}$ & $11.5 \mathrm{a}$ & $7199 \mathrm{a}$ & $65.9 \mathrm{a}$ & $6.1 \mathrm{a}$ & $124.4 \mathrm{a}$ & $755 a$ \\
\hline $\mathrm{S}_{1}\left(2 \mathrm{dS} \cdot \mathrm{m}^{-1}\right)$ & $84.8 \mathrm{ab}$ & $10.4 \mathrm{~b}$ & $6008 \mathrm{ab}$ & $56.5 \mathrm{ab}$ & $5.2 \mathrm{~b}$ & $121.5 \mathrm{a}$ & $645 \mathrm{~b}$ \\
\hline $\mathrm{S}_{2}\left(4 \mathrm{dS} \cdot \mathrm{m}^{-1}\right)$ & $80.8 \mathrm{~b}$ & $10.3 \mathrm{~b}$ & $5439 \mathrm{~b}$ & $49.5 \mathrm{~b}$ & $4.3 \mathrm{c}$ & $119.1 \mathrm{a}$ & $498 \mathrm{c}$ \\
\hline \multicolumn{8}{|l|}{ Biochar (B) } \\
\hline $\mathrm{B}_{0}$ (non-biochar) & $70.3 \mathrm{~b}$ & $8.4 \mathrm{~b}$ & $3469 \mathrm{~b}$ & $29.7 \mathrm{~b}$ & $2.8 \mathrm{~b}$ & $118.8 \mathrm{a}$ & $326 \mathrm{~b}$ \\
\hline $\mathrm{B}_{\mathrm{h}}$ (hardwood) & $93.3 \mathrm{a}$ & $11.8 \mathrm{a}$ & $7723 \mathrm{a}$ & $74.9 \mathrm{a}$ & $6.3 \mathrm{a}$ & $124.8 \mathrm{a}$ & $785 \mathrm{a}$ \\
\hline $\mathrm{B}_{\mathrm{s}}($ softwood) & $93.0 \mathrm{a}$ & $12.2 \mathrm{a}$ & $7586 \mathrm{a}$ & $68.2 \mathrm{a}$ & $6.6 \mathrm{a}$ & $121.4 \mathrm{a}$ & $802 \mathrm{a}$ \\
\hline (SXB) & NS & NS & NS & NS & NS & NS & NS \\
\hline
\end{tabular}

${ }^{\mathrm{z}}$ Values within a column followed by same letter are not significantly different according to a least significant difference test at $P \leq 0.05$.

$\mathrm{NS}=$ nonsignificant at $P \leq 0.05$.

$\mathrm{SXB}=$ salinity into biochar interaction. 


\begin{tabular}{|c|c|c|c|c|c|}
\hline \multirow[b]{2}{*}{ Treatments } & \multirow[b]{2}{*}{$\operatorname{RLD}\left(\mathrm{cm} \cdot \mathrm{cm}^{-3}\right)$} & \multirow[b]{2}{*}{$\operatorname{RSAD}\left(\mathrm{cm}^{2} \cdot \mathrm{cm}^{-3}\right)$} & \multicolumn{3}{|c|}{$\%$ total root length in a diam class } \\
\hline & & & $(0.0-0.5 \mathrm{~mm})$ & $(0.5-1.0 \mathrm{~mm})$ & $(>1.0 \mathrm{~mm})$ \\
\hline \multicolumn{6}{|l|}{ Expt. 1} \\
\hline \multicolumn{6}{|l|}{ Salinity level (S) } \\
\hline $\mathrm{S}_{0}$ (control) & $1.025 \mathrm{a}^{\mathrm{z}}$ & $0.085 \mathrm{a}$ & $93.570 \mathrm{a}$ & $6.231 \mathrm{a}$ & $0.198 \mathrm{a}$ \\
\hline $\mathrm{S}_{1}\left(2 \mathrm{dS} \cdot \mathrm{m}^{-1}\right)$ & $0.860 \mathrm{ab}$ & $0.068 \mathrm{ab}$ & $92.632 \mathrm{a}$ & $6.844 \mathrm{a}$ & $0.524 \mathrm{a}$ \\
\hline $\mathrm{S}_{2}\left(4 \mathrm{dS} \cdot \mathrm{m}^{-1}\right)$ & $0.392 \mathrm{~b}$ & $0.039 \mathrm{~b}$ & $89.519 \mathrm{a}$ & $9.068 \mathrm{a}$ & $1.413 \mathrm{a}$ \\
\hline \multicolumn{6}{|l|}{ Biochar (B) } \\
\hline $\mathrm{B}_{0}$ (non-biochar) & $0.597 \mathrm{~b}$ & $0.050 \mathrm{~b}$ & $89.396 \mathrm{a}$ & $8.675 \mathrm{a}$ & $1.929 \mathrm{a}$ \\
\hline $\mathrm{B}_{\mathrm{h}}$ (hardwood) & $0.771 \mathrm{ab}$ & $0.065 \mathrm{ab}$ & $91.721 \mathrm{a}$ & $8.130 \mathrm{a}$ & $0.149 \mathrm{a}$ \\
\hline$B_{\text {s }}$ (softwood) & $0.881 \mathrm{a}$ & $0.076 \mathrm{a}$ & $94.245 \mathrm{a}$ & $5.541 \mathrm{a}$ & $0.214 \mathrm{a}$ \\
\hline$(\mathrm{SXB})^{\mathrm{x}}$ & NS & NS & NS & NS & NS \\
\hline \multicolumn{6}{|l|}{ Expt. 2} \\
\hline \multicolumn{6}{|l|}{ Salinity level (S) } \\
\hline $\mathrm{S}_{0}$ (control) & $6.062 \mathrm{a}$ & $0.678 \mathrm{a}$ & $87.129 \mathrm{a}$ & $10.122 \mathrm{~b}$ & $2.749 \mathrm{~b}$ \\
\hline $\mathrm{S}_{1}\left(2 \mathrm{dS} \cdot \mathrm{m}^{-1}\right)$ & $5.246 \mathrm{a}$ & $0.583 \mathrm{ab}$ & $85.332 \mathrm{ab}$ & $11.400 \mathrm{ab}$ & $3.268 \mathrm{a}$ \\
\hline $\mathrm{S}_{2}\left(4 \mathrm{dS} \cdot \mathrm{m}^{-1}\right)$ & $4.971 \mathrm{a}$ & $0.546 \mathrm{~b}$ & $83.907 \mathrm{~b}$ & $12.685 \mathrm{a}$ & $3.409 \mathrm{a}$ \\
\hline \multicolumn{6}{|l|}{ Biochar (B) } \\
\hline $\mathrm{B}_{0}$ (non-biochar) & $1.710 \mathrm{~b}$ & $0.183 \mathrm{~b}$ & $84.595 \mathrm{a}$ & $11.366 \mathrm{a}$ & $4.039 \mathrm{a}$ \\
\hline $\mathrm{B}_{\mathrm{h}}$ (hardwood) & $7.760 \mathrm{a}$ & $0.852 \mathrm{a}$ & $85.896 \mathrm{a}$ & $11.290 \mathrm{a}$ & $2.814 \mathrm{~b}$ \\
\hline $\mathrm{B}_{\mathrm{s}}$ (softwood) & $6.952 \mathrm{a}$ & $0.788 \mathrm{a}$ & $85.926 \mathrm{a}$ & $11.564 \mathrm{a}$ & $2.51 \mathrm{~b}$ \\
\hline$(\mathrm{SXB})^{\mathrm{x}}$ & NS & NS & $\mathrm{NS}$ & $\mathrm{NS}$ & NS \\
\hline
\end{tabular}

${ }^{\mathrm{z} V a l u e s}$ within a column followed by same letter are not significantly different according to a least significant difference test at $P \leq 0.05$.

NS = nonsignificant at $P \leq 0.05$.

$\mathrm{RLD}=$ root length density; $\mathrm{RSAD}=$ root surface area density; $\mathrm{SXB}=$ salinity into biochar interaction.

of electrolyte leakage measured during the fruiting stage demonstrated that there was higher electrolyte leakage in the higher salinity treatments, which could have also affected the photosynthesis rate. Overall, all the physiological measures suggest that increased levels of salinity negatively affected $\mathrm{CO}_{2}$ assimilation. Because of reduced $\mathrm{CO}_{2}$ assimilation in the higher salinity treatments, plant growth was suppressed in the higher salinity treatments. However, reduced plant growth in the higher salinity treatments might not be only due to reduced photosynthesis rate per unit leaf area. It might have also decreased in response to a decrease in net photosynthetically active leaf area per plant in the higher salinity treatments (Munns and Tester, 2008). Under salinity stress, reduced water uptake results in a decline in leaf turgor. Cell expansion depends on the cell turgor. So, under salinity stress, cell expansion is inhibited, which further leads to a reduction in leaf elongation rate, subsequently reducing the leaf area growth rate (Jones, 1990). Leaves are the prime interface for mass exchange and energy between plants and the atmosphere. Most of the key plant processes such as canopy light interception, respiration, transpiration, element deposition, and $\mathrm{CO}_{2}$ assimilation are highly dependent on the leaf area (Pokovai and Fodor, 2019). Overall, in the higher salinity treatments, plant growth decreased due to a decrease in photosynthesis rate per unit of leaf area and also due to a reduction in leaf area per plant, which further affects the key plant processes important for plant growth and yield. In the present study, leaf area and $P_{n}$ decreased in the higher salinity treatments, which could have further caused the reduction in plant growth and fruit yield in the higher salinity treatments.

Previous studies have demonstrated that biochar addition enhances the crop productivity by improving the soil's physical, chem- ical, and biological properties (Lehmann and Joseph, 2009; Singh et al., 2019; Sohi et al., 2010). Improved soil properties (such as soil aggregate stability and saturated hydraulic conductivity) enhance the removal of salts from the root-zone through increased leaching of excess salts (Chaganti et al., 2015). Biochar has a high adsorption capacity, and it adsorbs $\mathrm{Na}^{+}$to inhibit its uptake by the plant (Akhtar et al., 2015b; Thomas et al., 2013). Biochar application enhances soil exchangeable $\mathrm{Ca}^{2+}$, which displaces $\mathrm{Na}^{+}$from exchange sites - and thus the leaching of $\mathrm{Na}^{+}$ gets enhanced, and the uptake of salts by plants gets reduced (Chaganti et al., 2015). Moreover, biochar application increases the soil water availability, which may cause the dilution of the comparatively concentrated soil solution (Akhtar et al., 2015b). Thus biochar addition reduces osmotic stress and enhances the water uptake for better plant growth. In the present study, the effectiveness of biochar addition to mitigate the negative impact of salt stress is evident from the increased $g_{\mathrm{S}}$ and photosynthesis rate, and more negative LATD in treatments amended with biochar. Reduced electrolyte leakage in the treatments amended with biochar further supports that biochar reduces the uptake of salts by the plants; and thus biochar helps to mitigate the ionic stress in plants. A better physiological status of plants in the treatments amended with biochar led to better plant growth (plant height, stem diameter, and leaf area). Subsequently these enhancements led to a better fruit yield in the treatments amended with biochar, with respect to non-biochar (control).

Root growth. The RLD was negatively affected by increased salinity levels (Table 3). In Expt. 1, RLD was not significantly different between the $\mathrm{S}_{0}$ and $\mathrm{S}_{1}$ (and also between the $S_{1}$ and $S_{2}$ ), while it was significantly different between the $S_{0}$ and $S_{2}$. In Expt. 2, RLD was not significantly differ- ent among the salinity treatments. It was the highest in $\mathrm{S}_{0}$ followed by $\mathrm{S}_{1}$, and it was found to be the lowest in $\mathrm{S}_{2}$. Biochar addition boosted the RLD. In Expt. 1, RLD was significantly higher in $B_{s}$ than $B_{0}$, but it did not differ significantly between $B_{h}$ and $B_{0}$. In Expt. 2, the RLD of $B_{s}$ and $B_{h}$ was significantly higher than $\mathrm{B}_{0}$, while it was not significantly different between $\mathrm{B}_{\mathrm{h}}$ and $\mathrm{B}_{\mathrm{s}}$.

The RSAD was negatively impacted in higher salinity levels. The RSAD was statistically similar between $\mathrm{S}_{0}$ and $\mathrm{S}_{1}$ and also between $S_{1}$ and $S_{2}$, while it was significantly higher in $S_{0}$ than $S_{2}$ in both experiments. Biochar addition enhanced the RSAD. In Expt. 1, RSAD was significantly higher only in $\mathrm{B}_{\mathrm{s}}$; while in Expt. 2, RSAD was higher in both $B_{h}$ and $B_{s}$ than $B_{0}$. It was not significantly different between $B_{h}$ and $B_{s}$ in both experiments.

Root length distribution (percent of total root length) in different diameter classes is reported in Table 3 . In both experiments and in all the treatments, the most fraction $(83 \%$ to $94 \%$ ) of total root length was lying in the diameter class of $0.0-0.5 \mathrm{~mm}$, while $6 \%$ to $13 \%$ and $0 \%$ to $4 \%$ of total root length were lying in diameter classes of $0.5-1.0 \mathrm{~mm}$ and $>1 \mathrm{~mm}$, respectively. This means that eggplant had more percentage of fine roots $(0.0$ $0.5 \mathrm{~mm}$ diameter), and it had very few comparatively thicker roots $(>0.5 \mathrm{~mm}$ diameter $)$. In Expt. 1, among the salinity treatments, $\mathrm{S}_{0}$ had allocated the highest fraction $(93.57 \%)$ of total root length to a diameter class of 0.0 $0.5 \mathrm{~mm}$, while $\mathrm{S}_{2}$ had allocated the highest fraction to $0.5-1.0 \mathrm{~mm}(9.068 \%)$ and $>1 \mathrm{~mm}$ $(1.413 \%)$ diameter classes. Similarly, in Expt. 2, among the salinity treatments, $\mathrm{S}_{0}$ and $\mathrm{S}_{2}$ had allocated the highest fraction ( $87.129 \%$ and $12.685 \%$, respectively) to diameter classes of $0.0-0.5 \mathrm{~mm}$ and 0.5 $1.0 \mathrm{~mm}$, respectively. Also, $\mathrm{S}_{2}$ had allocated the highest fraction $(3.409 \%)$ to $>1 \mathrm{~mm}$ diameter class. Based on these results, it can be 
interpreted that with an increase in salinity levels, root thickness increased to some extent. Biochar addition had no significant effect on root length distribution. In Expt. 1, among the biochar treatments, $\mathrm{B}_{\mathrm{s}}$ had allocated the highest fraction $(94.245 \%)$ of total root length to diameter class of $0.0-0.5 \mathrm{~mm}$, while $\mathrm{B}_{0}$ had allocated the highest fraction to $0.5-1.0 \mathrm{~mm}(8.675 \%)$ and $>1 \mathrm{~mm}(1.929 \%)$ diameters classes. In Expt.2, among the biochar treatments, $B_{\mathrm{s}}$ had allocated the highest fraction $(85.926 \%)$ of total root length to diameter class of $0.0-0.5 \mathrm{~mm}$, while $\mathrm{B}_{\mathrm{s}}$ and $\mathrm{B}_{0}$ allocated the highest fractions (11.564\% and $4.039 \%$, respectively) to diameter classes of $0.5-1.0 \mathrm{~mm}$ and $>1 \mathrm{~mm}$, respectively. Salinity inhibits the root extension by directly inhibiting the cell wall extensibility (Bressan et al., 1990). Cell expansion is a key factor affecting plant morphogenesis. The $\mathrm{Ca}^{2+}$ inflow from an extracellular store is needed for cell elongation in roots (Cramer and Jones, 1996). However, an increased concentration of $\mathrm{Na}^{+}$in the root zone causes a decline in $\mathrm{Ca}^{2+}$ influx. Additionally, an increase in accumulation of salts in the root zone induces oxidative stress, which further results in the generation of ROS (Hernandez et al., 1993; Shalata and Tal, 1998). These ROS cause lipid peroxidation in root cells and subsequently cause the death of roots cells (Katsuhara et al., 2005). Furthermore, salts stress results in a decline in cell turgor, which causes a reduction in cell elongation and root growth rate. In the present study, RLD decreased with increase in the salinity levels. In a study on tomato, Snapp and Shennan (1992) had observed that RLD decreased with increased salinity levels. Caines and Shennan (1999) had also observed that root length was lower in higher salinity treatments. It can be inferred that generally RLD decreases under salinity stress. The RSAD of eggplant also decreased with increased salinity levels, which was due to a decrease in RLD. Mohammad et al. (1998) also observed that the RSAD of tomato decreased with increased salinity levels. A decrease in RLD and RSAD reduces the net absorption area for water and nutrient uptake. Thus, a decrease in root growth negatively affects plant growth and yield. Biochar application significantly enhanced the root growth, possibly by improving the soil properties and by inhibiting the uptake of $\mathrm{Na}^{+}$through the roots. In studies on common bean, it was observed that biochar application had considerably enhanced the root growth (Farhangi-Abriz and Torabian, 2017, 2018b; Luo et al., 2017). Farhangi-Abriz and Torabian (2018b) found that biochar addition reduced $\mathrm{Na}^{+}$content in the roots under salt stress. Lower $\mathrm{Na}^{+}$content in roots is favorable for root growth. Consequently biochar addition increases the root growth and ultimately enhances plant growth and yield under salinity stress.

\section{Conclusions}

The increased salinity levels of irrigation water significantly decreased $g_{\mathrm{S}}$ and photo- synthesis rate, while the higher salinity levels increased leaf temperature and electrolyte leakage in leaf tissues. Additionally, a considerable decrease in root growth, shoot growth, and yield components was observed in the higher salinity treatments. However, biochar addition was effective to reduce the suppressing effect of increased salinity stress. Biochar application to the soil enhanced the physiological processes, root growth, shoot growth, and yield of eggplant. Both types of biochar had a comparable effect on physiology, growth, and yield of eggplant. Based on these results, it can be concluded that softwood and hardwood biochar have the potential to mitigate the negative impacts of salt stress in eggplant.

\section{Literature Cited}

Abbas, W., M. Ashraf, and N.A. Akram. 2010. Alleviation of salt-induced adverse effects in eggplant (Solanum melongena L.) by glycinebetaine and sugarbeet extracts. Scientia Hort. 125:188-195, doi: 10.1016/j.scienta.2010.04.008.

Agbna, G., A. Ali1, A. Bashir, F. Eltoum, and M. Hassan. 2017. Influence of biochar amendment on soil water characteristics and crop growth enhancement under salinity stress. Intl. J. Eng. Works, Kambohwell Publishers Enterprise 4:49-54.

Akhtar, S.S., M.N. Andersen, and F. Liu. 2015a. Biochar mitigates salinity stress in potato. J. Agron. Crop Sci. 201:368-378, doi: 10.1111/ jac. 12132.

Akhtar, S.S., M.N. Andersen, and F. Liu. 2015b. Residual effects of biochar on improving growth, physiology and yield of wheat under salt stress. Agr. Water Mgt. 158:61-68, doi: 10.1016/j.agwat.2015.04.010.

Akhtar, S.S., M.N. Andersen, M. Naveed, Z.A. Zahir, and F. Liu. 2015c. Interactive effect of biochar and plant growth-promoting bacterial endophytes on ameliorating salinity stress in maize. Funct. Plant Biol. 42:770-781, doi: 10.1071/FP15054

Al-Wabel, M.I., A.R.A. Usman, A.S. Al-Farraj, Y.S. Ok, A. Abduljabbar, A.I. Al-Faraj, and A.S Sallam. 2019. Date palm waste biochars alter a soil respiration, microbial biomass carbon, and heavy metal mobility in contaminated mined soil. Environ. Geochem. Health 41:1705-1722, doi: 10.1007/s10653-017-0049-9.

Ali, S., M. Rizwan, M.F. Qayyum, Y.S. Ok, M. Ibrahim, M. Riaz, M.S. Arif, F. Hafeez, M.I. Al-Wabel, and A.N. Shahzad. 2017. Biochar soil amendment on alleviation of drought and salt stress in plants: A critical review. Environ. Sci. Pollut. Res. Intl. 24:12700-12712, doi: 10.1007/s11356-017-8904-x.

Ashraf, M. and P. Harris. 2004. Potential biochemical indicators of salinity tolerance in plants. Plant Sci. 166:3-16, doi: 10.1016/j.plantsci.2003.10.024.

Baath, G.S., M.K. Shukla, P.W. Bosland, R.L. Steiner, and S.J. Walker. 2017. Irrigation water salinity influences at various growth stages of Capsicum annuum. Agr. Water Mgt. 179:246253, doi: 10.1016/j.agwat.2016.05.028

Bajji, M., J.-M. Kinet, and S. Lutts. 2002. Osmotic and ionic effects of $\mathrm{NaCl}$ on germination, early seedling growth, and ion content of Atriplex halimus (Chenopodiaceae). Can. J. Bot. 80:297-304, doi: 10.1139/b02-008.

Behboudian, M., E. Törökfalvy, and R. Walker. 1986. Effects of salinity on ionic content, water relations and gas exchange parameters in some citrus scion rootstock combinations. Scientia
Hort. 28:105-116, doi: 10.1016/0304-4238(86) 90130-5.

Bhattarai, B., S. Singh, C.P. West, G.L. Ritchie, and C.L. Trostle. 2020a. Effect of deficit irrigation on physiology and forage yield of forage sorghum, pearl millet, and corn. Crop Sci. 60(4):2167-2179, doi: 10.1002/csc2.20171.

Bhattarai, B., S. Singh, C.P. West, G.L. Ritchie, and C.L. Trostle. 2020b. Water depletion pattern and water use efficiency of forage sorghum, pearl millet, and corn under water limiting condition. Agr. Water Mgt. 238:106206, doi: 10.1016/ j.agwat.2020.106206.

Blum, A. and A. Ebercon. 1981. Cell membrane stability as a measure of drought and heat tolerance in wheat. Crop Sci. 21:43-47, doi: 10.2135/ cropsci1981.0011183X002100010013x.

Bressan, R.A., D.E. Nelson, N.M. Iraki, P.C. LaRosa, N.K. Singh, P.M. Hasegawa, and N.C. Carita. 1990. Reduced cell expansion and changes in cell walls of plant cells adapted to $\mathrm{NaCl}$, p. 137-171. In: F. Katterman (ed.) Environmental injury to plants. Elsevier, Amsterdam, The Netherlands.

Caines, A.M. and C. Shennan. 1999. Interactive effects of $\mathrm{Ca}^{2+}$ and $\mathrm{NaCl}$ salinity on the growth of two tomato genotypes differing in $\mathrm{Ca}^{2+}$ use efficiency. Plant Physiol. Biochem. 37:569576, doi: 10.1016/S0981-9428(00)80109-6.

Camejo, D., P. Rodríguez, M.A. Morales, J.M. Dell'amico, A. Torrecillas, and J.J. Alarcón. 2005. High temperature effects on photosynthetic activity of two tomato cultivars with different heat susceptibility. J. Plant Physiol. 162:281-289, doi: 10.1016/j.jplph.2004.07.014.

Chaganti, V.N., D.M. Crohn, and J. Šimůnek. 2015. Leaching and reclamation of a biochar and compost amended saline-sodic soil with moderate SAR reclaimed water. Agr. Water Mgt. 158:255265, doi: 10.1016/j.agwat.2015.05.016.

Colla, G., Y. Roupahel, M. Cardarelli, and E. Rea 2006. Effect of salinity on yield, fruit quality, leaf gas exchange, and mineral composition of grafted watermelon plants. HortScience 41:622627, doi: 10.21273/HORTSCI.41.3.622.

Cramer, G. and R. Jones. 1996. Osmotic stress and abscisic acid reduce cytosolic calcium activities in roots of Arabidopsis thaliana. Plant Cell Environ. 19:1291-1298, doi: 10.1111/j.13653040.1996.tb00007.x.

Delfine, S., A. Alvino, M.C. Villani, and F. Loreto. 1999. Restrictions to carbon dioxide conductance and photosynthesis in spinach leaves recovering from salt stress. Plant Physiol. 119:1101-1106, doi: 10.1104/pp.119.3.1101.

Dionisio-Sese, M.L. and S. Tobita. 1998. Antioxidant responses of rice seedlings to salinity stress. Plant Sci. 135:1-9, doi: 10.1016/S01689452(98)00025-9.

FAO, 2018. FAOSTAT. The Food and Agriculture Organization (FAO) of United Nations.

Farhangi-Abriz, S. and S. Torabian. 2017. Antioxidant enzyme and osmotic adjustment changes in bean seedlings as affected by biochar under salt stress. Ecotoxicol. Environ. Saf. 137:64 70, doi: 10.1016/j.ecoenv.2016.11.029.

Farhangi-Abriz, S. and S. Torabian. 2018a. Biochar improved nodulation and nitrogen metabolism of soybean under salt stress. Symbiosis 74:215-223, doi: 10.1007/s13199-017-0509-0.

Farhangi-Abriz, S. and S. Torabian. 2018b. Biochar increased plant growth-promoting hormones and helped to alleviates salt stress in common bean seedlings. J. Plant Growth Regul. 37:591-601, doi: 10.1007/s00344-017-9756-9.

García-Legaz, M., J. Ortiz, A. Garcí-Lidón, and A. Cerda. 1993. Effect of salinity on growth, ion content and $\mathrm{CO}_{2}$ assimilation rate in lemon varieties 
on different rootstocks. Physiol. Plant. 89:427-432, doi: 10.1111/j.1399-3054.1993.tb05194.x.

Glenn, E.P., J.J. Brown, and E. Blumwald. 1999. Salt tolerance and crop potential of halophytes. Crit. Rev. Plant Sci. 18:227-255, doi: 10.1080/ 07352689991309207.

Hammer, E.C., M. Forstreuter, M.C. Rillig, and J. Kohler. 2015. Biochar increases arbuscular mycorrhizal plant growth enhancement and ameliorates salinity stress. Appl. Soil Ecol. 96:114-121, doi: 10.1016/j.apsoil.2015.07.014.

Hegazi, A.M., A.M. El-Shraiy, and A. Ghoname. 2015. Alleviation of salt stress adverse effect and enhancing phenolic anti-oxidant content of eggplant by seaweed extract. Gesunde Pflanzen 67:21-31. https://doi-org.lib-e2.lib.ttu.edu/10.1007/ s10343-014-0333-x.

Hernandez, J.A., F.J. Corpas, M. Gomez, L.A. Del Rio, and F. Sevilla. 1993. Salt-induced oxidative stress mediated by activated oxygen species in pea leaf mitochondria. Physiol. Plant. 89:103110, doi: 10.1111/j.1399-3054.1993.tb01792.x.

Heuer, B., A. Meiri, and J. Shalevet. 1986. Salt tolerance of eggplant. Plant Soil 95:9-13, doi: 10.1007/BF02378847.

Hudak, P.F. 2001. Sodium adsorption ratios and salinity levels in nine Texas aquifers: Implications for irrigated agriculture. Intl. J. Environ. Stud. 58:331-341, doi: 10.1080/00207230108711335.

Inyang, M.I., B. Gao, Y. Yao, Y. Xue, A. Zimmerman, A. Mosa, P. Pullammanappallil, Y.S. Ok, and X. Cao. 2016. A review of biochar as a lowcost adsorbent for aqueous heavy metal removal. Crit. Rev. Environ. Sci. Technol. 46:406-433, doi: 10.1080/10643389.2015.1096880.

Jones, H.G. 1990. Physiological aspects of the control of water status in horticultural crops. HortScience 25:19-26.

Kage, H., M. Kochler, and H. Stützel. 2000. Root growth of cauliflower (Brassica oleracea L. botrytis) under unstressed conditions: Measurement and modelling. Plant Soil 223:133147, doi: 10.1023/A:1004866823128.

Katsuhara, M., T. Otsuka, and B. Ezaki. 2005. Salt stress-induced lipid peroxidation is reduced by glutathione S-transferase, but this reduction of lipid peroxides is not enough for a recovery of root growth in Arabidopsis. Plant Sci. 169:369 373, doi: 10.1016/j.plantsci.2005.03.030.

Kim, H.-S., K.-R. Kim, J.E. Yang, Y.S. Ok, G. Owens, T. Nehls, G. Wessolek, and K.-H. Kim. 2016. Effect of biochar on reclaimed tidal land soil properties and maize (Zea mays L.) response. Chemosphere 142:153-159.

Lashari, M.S., Y. Ye, H. Ji, L. Li, G.W. Kibue, H. Lu, J. Zheng, and G. Pan. 2015. Biochar-manure compost in conjunction with pyroligneous solution alleviated salt stress and improved leaf bioactivity of maize in a saline soil from central China: A 2-year field experiment. J. Sci. Food Agr. 95:1321-1327, doi: 10.1002/jsfa.6825.

Lax, A., E. Díaz, V. Castillo, and J. Albaladejo. 1994. Reclamation of physical and chemical properties of a salinized soil by organic amendment. Arid Land Res. Manage. 8:9-17, doi: 10.1080/15324989309381374.

Lehmann, J. and S. Joseph. 2009. Biochar for environmental management: An introduction, p. 1-12. In: J. Lehmann and S. Joseph (eds.). Biochar for environmental management: Science and technology. Earthscan/Dunstan House, London, U.K.

Levitt, J. and J. Levitt. 1987. Responses of plants to environmental stresses. Academic Press, New York

Lian, F. and B. Xing. 2017. Black carbon (biochar) in water/soil environments: Molecular structure, sorption, stability, and potential risk. En- viron. Sci. Technol. 51:13517-13532, doi: 10.1021/acs.est.7b02528.

Lloyd, J., P. Kriedemann, and D. Aspinall. 1990. Contrasts between citrus species in response to salinisation: An analysis of photosynthesis and water relations for different rootstock-scion combinations. Physiol. Plant. 78:236-246, doi: 10.1111/j.1399-3054.1990.tb02087.x.

Luo, X., G. Liu, Y. Xia, L. Chen, Z. Jiang, H. Zheng, and Z. Wang. 2017. Use of biocharcompost to improve properties and productivity of the degraded coastal soil in the Yellow River Delta, China. J. Soils Sed. 17:780-789. https:// doi-org.lib-e2.lib.ttu.edu/10.1007/s11368-0161361-1.

Mcneil, P.L. and R.A. Steinhardt. 1997. Loss, restoration, and maintenance of plasma membrane integrity. J. Cell Biol. 137:1-4, doi: 10.1083/jcb.137.1.1.

Mohammad, M., R. Shibli, M. Ajlouni, and L. Nimri. 1998. Tomato root and shoot responses to salt stress under different levels of phosphorus nutrition. J. Plant Nutr. 21:1667-1680, doi: 10.1080/01904169809365512.

Munns, R. 2002. Comparative physiology of salt and water stress. Plant Cell Environ. 25:239 250, doi: 10.1046/j.0016-8025.2001.00808.x.

Munns, R. and M. Tester. 2008. Mechanisms of salinity tolerance. Annu. Rev. Plant Biol. 59:651-681, doi: 10.1146/annurev.arplant.59. 032607.092911 .

Nikpour-Rashidabad, N., A. Tavasolee, S. Torabian, and S. Farhangi-Abriz. 2019. The effect of biochar on the physiological, morphological and anatomical characteristics of mung bean roots after exposure to salt stress. Arch. Biol. Sci. 71:321-327. http://www.serbiosoc.org.rs/arch/ index.php/abs/article/view/3491.

Oo, A.N., C.B. Iwai, and P. Saenjan. 2015. Soil properties and maize growth in saline and nonsaline soils using cassava-industrial waste compost and vermicompost with or without earthworms. Land Degrad. Dev. 26:300-310, doi: 10.1002/ldr.2208

Osakabe, Y., K. Osakabe, K. Shinozaki, and L.-S.P. Tran. 2014. Response of plants to water stress. Front. Plant Sci. 5:86, doi: 10.3389/ fpls.2014.00086.

Panuccio, M., S.-E. Jacobsen, S.S. Akhtar, and A. Muscolo. 2014. Effect of saline water on seed germination and early seedling growth of the halophyte quinoa. AoB Plants 6. doi: 10.1093/ aobpla/plu047.

Parihar, P., S. Singh, R. Singh, V.P. Singh, and S.M. Prasad. 2015. Effect of salinity stress on plants and its tolerance strategies: A review. Environ. Sci. Pollut. Res. Intl. 22:4056-4075, doi: 10.1007/s11356-014-3739-1.

Parkash, V. and S. Singh. 2020. A review on potential plant-based water stress indicators for vegetable crops. Sustainability 12:3945, doi: $10.3390 /$ su12103945.

Pokovai, K. and N. Fodor. 2019. Adjusting ceptometer data to improve leaf area index measurements. Agronomy 9:866, doi: 10.3390/ agronomy9120866.

Qadir, M., E. Quillérou, V. Nangia, G. Murtaza, M. Singh, R.J. Thomas, P. Drechsel, and A.D. Noble. 2014. Economics of salt-induced land degradation and restoration. Natural Resources Forum 38(4):282-295.

Rizwan, M., S. Ali, M.F. Qayyum, M. Ibrahim, M. Zia-Ur-Rehman, T. Abbas, and Y.S. Ok. 2016. Mechanisms of biochar-mediated alleviation of toxicity of trace elements in plants: A critical review. Environ. Sci. Pollut. Res. Intl. 23:2230 2248, doi: 10.1007/s11356-015-5697-7.
Sahin, U., M. Ekinci, S. Ors, M. Turan, S. Yildiz, and E. Yildirim. 2018. Effects of individual and combined effects of salinity and drought on physiological, nutritional and biochemical properties of cabbage (Brassica oleracea var. capitata). Scientia Hort. 240:196-204, doi: 10.1016/j.scienta.2018.06.016.

Saifullah. S. Dahlawi, A. Naeem, Z. Rengel, and R. Naidu. 2018. Biochar application for the remediation of salt-affected soils: Challenges and opportunities. Sci. Total Environ. 625:320-335, doi: 10.1016/j.scitotenv. 2017.12.257.

Shalata, A. and M. Tal. 1998. The effect of salt stress on lipid peroxidation and antioxidants in the leaf of the cultivated tomato and its wild salt-tolerant relative Lycopersicon pennellii. Physiol. Plant. 104:169-174, doi: 10.1034/ j.1399-3054.1998.1040204.x.

Singh, A. 2019. Modeling root water uptake of cotton (Gossypium hirsutum L.) under deficit ubsurface drip irrigation in west Texas. Texas Tech University, MS.

Singh, M., R.K. Saini, S. Singh, and S.P. Sharma. 2019. Potential of integrating biochar and deficit irrigation strategies for sustaining vegetable production in water-limited regions: A review. HortScience 54:1872-1878, doi: 10.21273/HORTSCI1427119.

Singh, S., S.V. Angadi, R. St Hilaire, K. Grover, and D.M. Vanleeuwen. 2016. Spring safflower performance under growth stage based irrigation in the Southern High Plains. Crop Sci. 56:1878-1889, doi: $10.2135 /$ cropsci2 015 . 08.0481 .

Singh, S., K. Grover, S. Begna, S. Angadi, M. Shukla, R. Steiner, and D. Auld. 2014. Physiological response of diverse origin spring safflower genotypes to salinity. J. Arid Land Studies 24:169-174.

Snapp, S. and C. Shennan. 1992. Effects of salinity on root growth and death dynamics of tomato, Lycopersicon esculentum Mill. New Phytol. 121:71-79, doi: 10.1111/j.1469-8137.1992.tb01094.x.

Sohi, S.P., E. Krull, E. Lopez-Capel, and R. Bol. 2010. A review of biochar and its use and function in soil, p. 47-82. In: Advances in agronomy, vol. 105. Elsevier, Amsterdam, The Netherlands.

Srivastava, P.K., M. Gupta, N. Singh, and S.K. Tewari. 2016. Amelioration of sodic soil for wheat cultivation using bioaugmented organic soil amendment. Land Degrad. Dev. 27:12451254, doi: 10.1002/1dr.2292.

Stępień, P. and G. Kłbus. 2006. Water relations and photosynthesis in Cucumis sativus L. leaves under salt stress. Biol. Plant. 50:610. https://doi-org.libe2.lib.ttu.edu/10.1007/s10535-006-0096-z.

Testi, L., D. Goldhamer, F. Iniesta, and M. Salinas. 2008. Crop water stress index is a sensitive water stress indicator in pistachio trees. Irr. Sci. 26:395-405, doi: 10.1007/s00271-008-0104-5.

Thomas, S.C., S. Frye, N. Gale, M. Garmon, R. Launchbury, N. Machado, S. Melamed, J. Murray, A. Petroff, and C. Winsborough. 2013. Biochar mitigates negative effects of salt additions on two herbaceous plant species. J. Environ. Manage. 129:62-68, doi: 10.1016/ j.jenvman.2013.05.057.

Ünlükara, A., A. Kurunç, G.D. Kesmez, E. Yurtseven, and D.L. Suarez. 2010. Effects of salinity on eggplant (Solanum melongena L.) growth and evapotranspiration. Irrigation and Drainage: The Journal of the International Commission on Irrigation and Drainage 59:203-214. https://doi.org/10.1002/ird.453.

Usman, A.R.A., M.I. Al-Wabel, A.-H. Abdulaziz, W.-A. Mahmoud, A.H. El-Naggar, M. Ahmad, 
A.-F. Abdulelah, and A.-O. Abdulrasoul. 2016. Conocarpus biochar induces changes in soil nutrient availability and tomato growth under saline irrigation. Pedosphere 26:27-38, doi: 10.1016/S1002-0160(15)60019-4.

Walker, D.J. and M.P. Bernal. 2008. The effects of olive mill waste compost and poultry manure on the availability and plant uptake of nutrients in a highly saline soil. Bioresour. Technol. 99:396403, doi: 10.1016/j.biortech.2006.12.006.

Wang, B., B. Gao, and J. Fang. 2017. Recent advances in engineered biochar productions and applications. Crit. Rev. Environ. Sci. Technol. 47:21582207, doi: $10.1080 / 10643389.2017 .1418580$.

Wang, M., Q. Zheng, Q. Shen, and S. Guo. 2013. The critical role of potassium in plant stress response. Intl. J. Mol. Sci. 14:7370-7390, doi: 10.3390/ijms 14047370 .

Wicke, B., E. Smeets, V. Dornburg, B. Vashev, T. Gaiser, W. Turkenburg, and A. Faaij. 2011. The global technical and economic potential of bioenergy from salt-affected soils. Energy Environ. Sci. 4:2669-2681, doi: 10.1039/c1ee01029h.

Yaduvanshi, N. and A. Swarup. 2005. Effect of continuous use of sodic irrigation water with and without gypsum, farmyard manure, pressmud and fertilizer on soil properties and yields of rice and wheat in a long term experiment Nutr. Cycl. Agroecosyst. 73:111-118, doi: 10.1007/s10705-005-3361-1.

Yeo, A. and T. Flowers. 1986. Salinity resistance in rice (Oryza sativa L.) and a pyramiding ap- proach to breeding varieties for saline soils. Funct. Plant Biol. 13:161-173, doi: 10.1071/ PP9860161.

Yue, Y., W. Guo, Q. Lin, G. Li, and X. Zhao 2016. Improving salt leaching in a simulated saline soil column by three biochars derived from rice straw (Oryza sativa L.), sunflower straw (Helianthus annuus), and cow manure. J. Soil Water Conserv. 71:467-475, doi: 10.2489/jswc.71.6.467.

Zahir, Z.A., S.S. Akhtar, M. Ahmad, Saifullah, and S.M. Nadeem. 2012. Comparative effectiveness of Enterobacter aerogenes and Pseudomonas fluorescens for mitigating the depressing effect of brackish water on maize. Intl. J. Agr. Biol. 14:337-344. 